MEDFARM: Jurnal Farmasi dan Kesehatan, Vol 1, No 1., 2021, Hal. 1-10

e-ISSN : 2715-9957

p-ISSN: 2354-8487

\title{
PENGARUH KONSELING TENAGA KEFARMASIAN DALAM PELAYANAN, EDUKASI, DAN SWEMEDIKASI TERHADAP PASIEN DI APOTEK ASYA FARMA BANDUNGAN
}

\author{
Indira Aprilia Putri1, Mei Ika Nurul Kotimah², Muhamad Faizur Rasyid Al Fajri³, Siti \\ Nur Indriyah", Wanda Nur Alifah', Aris Prio Agus Santoso ${ }^{6}$ \\ 1,2,3,4,5,6)Universitas Duta Bangsa Surakarta \\ 1) indiraapriliaputri@gmail.com
}

\begin{abstract}
ABSTRAK
Pada era modern ini tenaga kefarmasian dituntut untuk bekomunikasi dengan baik, karena ini penting dalam pelayanan obat pada pasien. Banyak terjadi kekurang pahaman pasien terhadap pemakaian obat karna kurangnya komunikasi. Maka, penelitian ini dilakukan guna meningkatkan pengetahuan pasien terhadap penggunaan obat yang baik dan benar agar dapat melakukan swamedikasi sendiri dirumah. Permasalahan dalam penelitian ini adalah bagaimana meningkatkan kesadaran masyarakat agar mau bertanya dan berkonsultasi dengan Apoteker tentang penggunaan obat yang baik. Metode penelitian yang digunakan dalam penelitian ini adalah metode survei. Penelitian survei diaplikasikan guna mengoleksi informasi dan data mengenai populasi, memakai sampel yang relative kecil. Bentuk penelitian yang digunakan dalam jurnal ini adalah deskriptif dimana prosedur penelitian atau pemecahan masalah yang diselidiki dengan gambaran subjek atau objek, dan menggunakan teknik pengumpulan data primer yaitu dengan data yang dikumpulkan sendiri. Dalam penelitian ini diperoleh hasil bahwa masih banyak masyarakat yang minim akan pengetahuan tentang penggunaan obat yang baik dan benar serta masyarakat banyak yang tidak mau melakukan konseling dengan Apoteker langsung.
\end{abstract}

Kata Kunci : pelayanan, konseling, swamedikasi 
MEDFARM: Jurnal Farmasi dan Kesehatan, Vol 1, No 1., 2021, Hal. 1-10

e-ISSN : 2715-9957

p-ISSN: $2354-8487$

\begin{abstract}
In this modern era, pharmaceutical personnel are required to communicate well, because this is important in drug service to patients. Many patients lack understanding of drug use due to lack of communication. So, this research was conducted in order to increase the patient's knowledge of the proper and correct use of drugs so that they can do self-medication at home. The problem in this research is how to increase public awareness so that they want to ask questions and consult with pharmacists about the good use of drugs. The research method used in this research is a survey method. Survey research is applied to collect information and data about a population, using a relatively small sample. The form of research used in this journal is descriptive where the research procedure or problem solving is investigated with a description of the subject or object, and uses primary data collection techniques, namely the data collected by themselves. In this study, the results showed that there are still many people who have minimal knowledge about the proper and correct use of drugs and many people do not want to do counseling with pharmacists directly.

Keywords: service, counseling, self-medication
\end{abstract}

\title{
PENDAHULUAN
}

\section{Latar Belakang}

Saat ini pelayanan kefarmasian tidak hanya berorientasi terhadap produk melainkan juga berorientasi terhadap pasien. Dimana masyarakat mulai sadar akan peran apoteker di apotek, hal ini dibuktikan dengan banyaknya masyarakat yang menuntut pelayanan kefarmasian yang bermutu, dan mulai berdiskusi tentang permasalahan terkait penggunaan obat, serta permasalahan terkait farmakososio-ekonomi. Sesuai dengan PerMenKes No. 73 Tahun 2016 tentang Standar Pelayanan Kefarmasian di apotek, salah satu upaya apoteker dalam membantu masyarakat dalam menyelesaikan masalah terkait kesehatan dan pengobatannya serta dalam meningkatkan mutu kehidupan pasien adalah memberikan konseling terkait penggunaan obat yang benar.

Menurut KEPMENKES RI No. 1027/MENKES/SK/IX/2004 tentang Standar Pelayanan Kefarmasian di apotik, konseling adalah suatu proses komunikasi dua arah yang 
MEDFARM: Jurnal Farmasi dan Kesehatan, Vol 1, No 1., 2021, Hal. 1-10

e-ISSN : 2715-9957

p-ISSN: 2354-8487

sistematik antara apoteker dan pasien untuk mengidentifikasi dan memecahkan masalah yang berkaitan dengan obat dan pengobatan. Proses konseling merupakan metode cara untuk meningkatkan pengetahuan dan pemahaman pasien dalam penggunaan obat agar tidak terjadi hal-hal yang tidak diinginkan. Sehingga untuk menghindari hal tersebut terdapat istilah Pharmaceutical care atau pelayanan yang dibutuhkan dan diterima pasien untuk menjamin keamanan dan penggunaan obat yang rasional, baik sebelum, selama, maupun sesudah penggunaan obat guna untuk memenuhi kebutuhan peningkatan pelayanan kesehatan terkait adanya peresepan ganda untuk satu orang pasien, banyaknya obat-obat baru yang bermunculan, kebutuhan akan informasi obat, angka kesakitan dan kematian yang terkait dengan penggunaan obat serta tingginya pengeluaran pasien untuk biaya kesehatan akibat penggunaan obat yang tidak tepat.

Berkaitan dengan hal tersebut maka perlu dilakukan penelitian untuk mengetahui pengaruh konseling tenaga kefarmasian dalam pelayanan, edukasi, dan swemedikasi pada pasien. Dalam proses konseling apoteker dapat menyampaikan informasi kepada pasien harus lengkap dan jelas, yaitu cara pakai obat, efek samping obat, indikasi, kontraindikasi, dosis, interaksi obat, mekanisme aksi, penggunaan ibu hamil dan menyusui. Informasi tersebut merupakan poin-poin penting yang harus dipahami oleh pasien guna menghindari terjadinya medication error.

Medical error merupakan kejadian yang menyebabkan atau berakibat pada pelayanan kesehatan yang tidak tepat atau membahayakan pasien yang sebenarnya dapat dihindari. Institute of Medication (IOM) melaporkan adanya kejadian yang tidak diharapkan (KTD) pada pasien rawat inap di Amerika sebanyak 44.000 bahkan 98.000 orang meninggal karena medical error (kesalahan dalam pelayanan medis) dan 7.000 kasus karena medication error (ME).(Kohn L et al., 2000). Faktor yang paling sering mempengaruhi medication error adalah faktor individu, berupa persoalan pribadi, pengetahuan tentang obat yang kurang memadai, dan kesalahan perhitungan dosis obat (Mansouri et al., 2014). Kesalahan pada salah satu tahap akan menimbulkan kesalahan pada tahap selanjutnya.

Berkaitan hal tersebut maka perlu dilakukan penelitian untuk mengetahui pengaruh konseling tenaga kefarmasian dalam pelayanan, edukasi, dan swemedikasi diterapkan di 
MEDFARM: Jurnal Farmasi dan Kesehatan, Vol 1, No 1., 2021, Hal. 1-10

e-ISSN : 2715-9957

p-ISSN: 2354-8487

apotek Asya Farma Bandungan terhadap pemahaman pasien mengenai obat yang digunakan untuk menghindari terjadinya medication error.

\section{Rumusan Masalah}

Perumusan masalah dalam penelitian ini adalah sebagai berikut :

1. Bagaimana pengaruh konseling tenaga kefarmasian dalam pelayanan, edukasi, dan swemedikasi terhadap pasien di apotek?

\section{Metode penelitian}

1. Metode penelitian

Metode penelitian yang digunakan dalam penelitian ini adalah metode survei. Penelitian survei diaplikasikan guna mengoleksi informasi maupun data mengenai populasi yang besar dengan memakai sampel yang relative kecil. Populasi bisa mengikuti dan berhubungan dengan instansi lembaga orang organisasi maupun unitunit kemasyarakatan dan sebagainya namun sumber paling utamanya ialah orang.

2. Bentuk penelitian

Bentuk penelitianyang digunakan dalam jurnal ini adalah deskriptif dimana prosedur penelitian atau pemecahan masalah yang diselidiki dengan gambaran subjek atau objek yang berupa orang,lembaga,masyarakat dan yang lainnya.

3. Teknik pengumpulan data

Teknik pengumpulan data pada penelitian ini adalah berdasarkan data primer yaitu data yang dikumpulkan oleh peneliti sendiri atau dirinya sendiri. Ini adalah data yang belum pernah dikumpulkan sebelumnya, baik dengan cara tertrntu atau pada periode waktu tertentu.

4. Analisis data

Analisis data pada penelitian ini adalah dengan metode analisis data kualitatif analisis wacana. Data kualitatif sendiri adalah data yang tidak dapat diangkakan atau bersifat non numeric. Teknik analisis data kualitatif pada umumnya merupakan bahasan konseptual suatu permasalahan. Analisis wacana adalah teknik analisis yang 
MEDFARM: Jurnal Farmasi dan Kesehatan, Vol 1, No 1., 2021, Hal. 1-10

e-ISSN : 2715-9957

p-ISSN: 2354-8487

digunakan untuk menganalisis interaksi orang, analisis wacana lebih focus pada konteks social dimana komunikasi antara responden dan peneliti terjadi.

\section{HASIL DAN PEMBAHASAN}

Dari beberapa cara penelitian konseling diapotek pemilihan pelaksanaan konseling terhadap pasien, dengan rancangan Cross Sectional yaitu penelitian yang mendesain pengumpulan datanya dilakukan pada satu titik waktu (at one point in time) yang dilakukan di Apotek Asya farma Bandungan dan menggunakan metode survei. Penelitian survei diaplikasikan guna mengoleksi informasi maupun data mengenai populasi yang besar dengan memakai sampel yang relative kecil. Populasi bisa mengikuti dan berhubungan dengan instansi lembaga orang organisasi maupun unit-unit kemasyarakatan dan sebagainya namun sumber paling utamanya ialah orang tentunya dengan melakukan konseling terhadap pasien yang melakukan pembelian obat baik dengan resep ataupun tanpa resep.

Peneliti selalu diminta untuk berkonsultasi dengan Apoteker yang bertanggung jawab di Apotek Asya Farma Bandungan agar informasi yang didapat selalu tepat dan benar.Swamedikasi merupakan upaya pengobatan sendiri tanpa didasari resep Dokter. Menurut WHO, pengobatan swamedikasi ditujukan untuk menangani gejala dan penyakit yang mampu didiagnosis oleh pasien sendiri atau penggunaan obat yang telah digunakan secara terus-menerus untuk penanganan gejala kronis. Pada Tabel 1. memperlihatkan tingkat pemahaman pasien sebelum dilakukan konseling dikarenakan masih awam nya beberapa pasien terhadap pemahaman informasi obat dapat dilihat dari data tersebut bahwa masih banyak pasien yang membutuhkan konseling obat dengan apoteker agar tidak terjadi kesalahan dalam penggunakan obat yang menggunakan resep dokter.

Dapat dilihat dari hasil tabel 1. bahwa tingkat pemahaman pasien yang berkunjung di apotek asya Farma Bandungan tidak cukup untuk memenuhi pengetahuan tentang obat seperti cara penggunaan obat, waktu minum obat serta dosis yang diperlukan maka perlu adanya swamedikasi oleh apoteker yang tercantum pada pasal 21 Peraturan pemerintah nomor 51 tahun 2009 disebutkan bahwa yang melaksanakan penyerahan dan pelayanan 
MEDFARM: Jurnal Farmasi dan Kesehatan, Vol 1, No 1., 2021, Hal. 1-10

e-ISSN : 2715-9957

p-ISSN: 2354-8487

obat berdasarkan resep dokter haruslah seorang apoteker (Peraturan Pemerintah, 2009). Asisten apoteker tugasnya membantu apoteker dalam menyiapkan obat yang ada pada resep. Penjaminan mutu akhir serta penyerahan obat harus dilakukan oleh apoteker. Tabel tersebut didapat dari hasil data konseling dan swamedikasi obat di apotek Asya Farma Bandungan.

Tabel 1. Tingkat Pemahaman Pasien terhadap swamedikasi obat sebelum konseling oleh apoteker.

\begin{tabular}{|l|l|l|l|}
\hline No & Pasien & $\begin{array}{l}\text { Presentasi pemahaman } \\
\text { seputar obat }\end{array}$ & Kategori \\
\hline 1. & Ny. Sumarni & $53.7 \%$ & Tidak Cukup \\
\hline 2. & Ny. Karsinah & $46.7 \%$ & Tidak Cukup \\
\hline 3. & Bp. Joko & $89.5 \%$ & Cukup \\
\hline 4. & Ny. Siti nur & $60,2 \%$ & Tidak Cukup \\
\hline 5. & Bp. Wondo & $82.8 \%$ & Cukup \\
\hline 6. & Ny. Tutik & $56,1 \%$ & Tidak cukup \\
\hline
\end{tabular}

Untuk mengetahui peningkatan tingkat pemahaman pasien terhadap obat perlu adanya konseling yang terarah agar pasien dapat benar benar paham tentang obat yang dibutuhkan pasien yang tentunya menggunakan resep dokter yaitu resep untuk pasien yang menderita penyakit diabetes, dan penyakit TBC sesuai dengan standar.pelayanan kefarmasian di apotek, kelompok pasien tersebut adalah kelompok prioritas yang perlu diberikan konseling oleh apoteker. Pasien dengan penyakit degeneratif seperti diabetes dan TBC yang berpeluang untuk menggunakan obat sepanjang hidupnya sehingga berkemungkinan akan mengalami masalah kepatuhan minum obat. Serta diharapkan pasien dapat melakukan swamedikasi sendiri. Swamedikasi berarti mengobati segala keluhan pada diri sendiri dengan obat-obat yang di beli bebas di Apotek atau di toko obat atas inisiatif sendiri tanpa nasehat dokter. Hal ini bukan dikarenakan tindakan swamedikasi lebih efektif dibanding pengobatan melalui diagnosa dokter, melainkan karena tindakan swamedikasi harganya lebih terjangkau dibandingkan berobat di instansi-instansi kesehatan. 
MEDFARM: Jurnal Farmasi dan Kesehatan, Vol 1, No 1., 2021, Hal. 1-10

e-ISSN : 2715-9957

p-ISSN: $2354-8487$

Konseling yang diberikan secara benar dan tepat oleh apoteker juga akan mempengaruhi meningkatnya pemahaman pasien terhadap obat yang dibutuhkan pasien, setelah dilakukan konseling dapat dilihat dari Tabel 2. bahwa adanya peningkatan signifikan terhadap pemahaman obat oleh pasien yang tentunya akan berpengaruh baik terhadap proses pengurangan rasa sakit yang diderita pasien.Salah satu penyakit umum yang sering diobati dengan cara swamedikasi yaitu penyakit maag (Misnadiarly, 2009). Maag merupakan penyakit gangguan pencernaan akibat tingginya kadar asam dalam lambung yang disebabkan oleh faktor psikis, obat-obat tertentu, dan makanan atau minuman yang merangsang tingginya kadar asam lambung (Parjimo et al., 2008, Azis et al., 2005). Peningkatan pemahan pasien terhadap penggunaan obat juga dipengaruhi oleh seberapa sering pasien pengunjungj apotek untuk membeli obat dan seberapa tanggap pasien dalam menanyakan obat yang dibutuhkan kepada Apoteker karena jika tidak bertanya mungkin akan terjadi kesalahan dalam penggunakan obat yang dibutuhkan pasien.

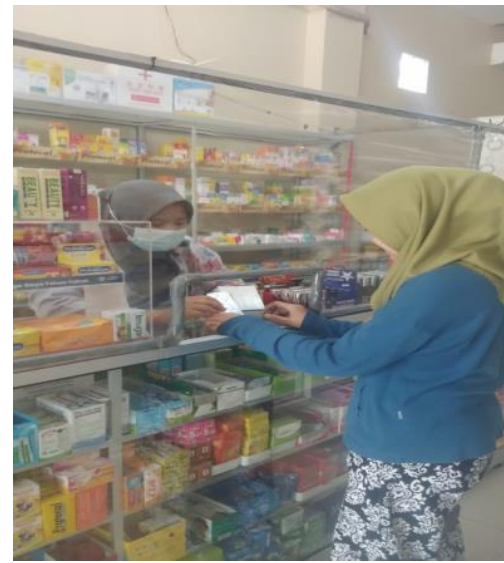

Gambar 1. Pemberian Konseling untuk Pemahaman Pasien terhadap swamedikasi obat oleh apoteker. 
MEDFARM: Jurnal Farmasi dan Kesehatan, Vol 1, No 1., 2021, Hal. 1-10

e-ISSN : 2715-9957

p-ISSN: $2354-8487$

Tabel 2. Tingkat Pemahaman pasien terhadap swamedikasi obat sesudah konseling oleh apoteker.

\begin{tabular}{|l|l|l|l|}
\hline No. & Pasien & $\begin{array}{l}\text { Presentasi pemahaman } \\
\text { seputar obat }\end{array}$ & Kategori \\
\hline 1. & Ny. Sumarni & $70,3 \%$ & Cukup \\
\hline 2. & Ny. Karsinah & $75,8 \%$ & Cukup \\
\hline 3. & Bp. Joko & $90,5 \%$ & Sangat Cukup \\
\hline 4. & Ny. Situ nur & $81,6 \%$ & Cukup \\
\hline 5. & Bp. Wondo & $88,9 \%$ & Cukup \\
\hline 6. & Ny. Tutik & $75,1 \%$ & Cukup \\
\hline
\end{tabular}

Dari data tabel 2. dapat dikatakan peningkatan pemahaman pasien terhadap obat yang dibutuhkan meningkat menjadi cukup baik dan diharapkan dapat melakukan swamedikasi sendiri dirumah karena menurut penelitian beberapa orang lebih banyak merasakan atau mendiagnosa sendiri penyakit yang di rasakan pasien dibanding harus membayar dan periksa ke dokter pengalaman pribadi sebanyak 67\%, karena pasien sudah cocok dan sering menggunakan obat tersebut. Sebagian besar pasien yang melakukan swamedikasi karena pengalaman pribadi adalah pasien yang telah melakukan swamedikasi berulang-ulang dengan gejala dan obat yang sama sehingga mereka merasa tidak perlu untuk ke dokter (Supardi et al, 2005). Apoteker dan tenaga pembantu lainnya harus secara maksimal dalam melakukan konseling terhadap pasien agar pasien juga semakin paham.

Penelitian ini dikatakan berhasil karena semua pihak yang terlibat melakukan perannya dengan sangat baik dan diharapkan pasien yang berkunjung ke apotek dapat membeli obat dengan tepat dengan penyakit yang dideritanya. Konseling ini merupakan sarana bagi apoteker untuk membantu pasien mengatasi masalah pengobatan yang sedang mereka jalani. Melalui konseling, apoteker dapat melakukan penilaian terhadap pemahaman pasien baik terhadap penyakit maupun obat yang sedang mereka gunakan. Beberapa penelitian melaporkan bahwa konseling oleh apoteker dapat mengatasi masalah kepatuhan yang rendah yang dialami oleh pasien (Kooij et al., 2016; Masserli et al., 2016). Diharapakan pasien dapat melakukan swamedikasi dirumah sendiri dengan baik dan dengan merasakan serta mendiagnosa sendiri penyakit yang diderita pasien agar saat 
MEDFARM: Jurnal Farmasi dan Kesehatan, Vol 1, No 1., 2021, Hal. 1-10

e-ISSN : 2715-9957

p-ISSN: 2354-8487

membeli obat tidak perlu bingung atau salah dan tentunya dapat bertanya langsung kepada Apoteker.

\section{Simpulan}

Setelah melakukan penelitian mengenai pengaruh konseling tenaga kefarmasian dalam pelayanan, edukasi dan swamedikasi terhadap pasien pengunjung Apotek Asya Farma penulis menyimpulkan bahwa :

1. Tenaga kefarmasian seperti apoteker berupaya untuk memberikan konseling terhadap pasien. Konseling yang diberikan secara tepat dan benar akan meningkatkan pemahaman pasien terhadap obat yang diperlukan dan meminimalisir kesalahan dalam penggunaan obat.

2. Masyarakat perlu memahami pentingnya konseling terhadap swamedikasi obat dan memiliki pemahaman agar tidak mengalami kebingungan bahkan terjadi kesalahan pada saat membeli obat. Tujuan dari swamedikasi sendiri adalah meningkatkan kepahaman masyarakat untuk mengetahui lebih dini gejala yang dirasakan dan mengetahui jenis obat apa yang cocok untuk meredakan penyakit yang diderita.

\section{Saran}

Saran untuk tenaga kefarmasian atau apoteker agar dapat memberikan konseling terhadap masyarakat secara tepat, benar, jelas dan rinci sampai masyarakat merasa paham untuk mengetahui lebih dini gejala yang diderita serta mengetahui obat apa yang diperlukan.

Saran untuk masyarakat agar lebih aktif bertanya kepada tenaga kefarmasian khususnya di Apotek agar mendapatkan informasi mengenai obat yang diperlukan sehingga dapat mengurangi kesalahan akibat pembelian obat serta penggunaannya yang tidak sesuai dengan gejala yang dirasakan.

\section{DAFTAR PUSTAKA}

Wardani, S.W., dkk. 2021. Pengantar Komunikasi Kesehatan, Jakarta: Trans Info Media. 
MEDFARM: Jurnal Farmasi dan Kesehatan, Vol 1, No 1., 2021, Hal. 1-10

e-ISSN : 2715-9957

p-ISSN: 2354-8487

Santoso, dkk. 2020, Etika Profesi Kefarmasian dan Hukum Kesehatan, Jakarta: Trans Info Media. Santoso dan Aris Prio A 2020, Hukum Kesehatan, Yogyakarta: Pustaka Baru.

Santoso, dkk. 2021. "Legal Protection of Health Worker in The Task Force for The Acceleration of Handling Covid-19 from a State Administrative Law Point ov View", Jurnal Ilmu Sosial dan Pendidikan, Vol.5, No. 1, 2021.

Suhatmi, E.C., dkk. 2021, "Pemutusan Hubungan Kerja di Tengah Pandemi Covid-19 Ditinjau dari Sudut Pandang Hukum Ketenagakerjaan", UNIFIKASI: Jurnal Ilmu Hukum, Vol. 8, No. 1, 2021.

Wardani, T.S., dkk. 2020, "Analisis Yuridis Kewenangan Perawat dalam Pemberian Obat-Obatan Label Merah pada Praktik Keperawatan Mandiri", Yurisprudentia: Jurnal Hukum Ekonomi, Vol. 6, No.1, 2020.

Yati,L.H., dkk, 2016, Pelaksanaan Konseling Oleh Apoteker di Apotek Kecamata Temanggung, Temanggung.

Anonim.2020. Diakses dari http:/ / repository.unissula.ac.id/16371/. pada tanggal 26 Maret 2020 